\title{
TU/e EmonOWEN

\section{The role of hydration and stereoelectronic effects in the hydrolysis of CAMP}

\section{Citation for published version (APA):}

Genderen, van, M. H. P., Koole, L. H., Kooyk, van, R. J. L., \& Buck, H. M. (1985). The role of hydration and stereoelectronic effects in the hydrolysis of cAMP. Journal of Organic Chemistry, 50(13), 2380-2383. https://doi.org/10.1021/j000213a038

DOI:

10.1021/jo00213a038

Document status and date:

Published: 01/01/1985

\section{Document Version:}

Publisher's PDF, also known as Version of Record (includes final page, issue and volume numbers)

\section{Please check the document version of this publication:}

- A submitted manuscript is the version of the article upon submission and before peer-review. There can be important differences between the submitted version and the official published version of record. People interested in the research are advised to contact the author for the final version of the publication, or visit the $\mathrm{DOI}$ to the publisher's website.

- The final author version and the galley proof are versions of the publication after peer review.

- The final published version features the final layout of the paper including the volume, issue and page numbers.

Link to publication

\section{General rights}

Copyright and moral rights for the publications made accessible in the public portal are retained by the authors and/or other copyright owners and it is a condition of accessing publications that users recognise and abide by the legal requirements associated with these rights.

- Users may download and print one copy of any publication from the public portal for the purpose of private study or research.

- You may not further distribute the material or use it for any profit-making activity or commercial gain

- You may freely distribute the URL identifying the publication in the public portal.

If the publication is distributed under the terms of Article 25fa of the Dutch Copyright Act, indicated by the "Taverne" license above, please follow below link for the End User Agreement:

www.tue.nl/taverne

Take down policy

If you believe that this document breaches copyright please contact us at:

openaccess@tue.nl

providing details and we will investigate your claim. 
acetoxynitrosamines. ${ }^{7}$ In this case, intramolecular nucleophilic displacement of the chloro by the hydroxyl group gives the cyclic nitrosamine.

$N$-Nitroso 2,2-disubstituted oxazolidines can now be prepared cleanly and in good yields with nitrosyl chloride and anhydrous potassium carbonate. it is not known at this time whether symmetrical 2,2-disubstitutions have any effect on the regioselectivity of alkylation or if it prevents multiple alkylations. However, the nuclear magnetic resonance data indicates that these nitrosamines exist as the $E$ rotamers. $N$-nitroso-2,2,4-trimethyloxazolidine (5) is an exception, with the $Z$ rotamer representing $3 \%$ of the mixture.

\section{Experimental Section}

Proton and NMR spectra were recorded on a Nicolet NT-300 spectrometer with $\mathrm{CDCl}_{3}$ as the solvent containing $0.5 \%$ tetramethylsilane. The IR spectra were obtained on a Perkin-Elmer 467 spectrometer. Low-resolution mass spectra were taken on a Finnigan 330 mass spectrometer equipped with a Finnigan 6000 MS data system. Gas chromatographic analyses were carried out on a Shimdazu Model 4BM gas chromatograph equipped with a Hewlett-Packard 18652A A/D converter coupled to the recorder of a flame ionization detector. A 2.5-m Tenax 80/100 GC column (Applied Science Division) was used.

N-Nitroso-2,2-dimethyloxazolidine (3). To a solution of 10 g $(0.16 \mathrm{~mol})$ of ethanolamine in $100 \mathrm{~mL}$ of methylene chloride were added $15 \mathrm{~g}$ of anydrous potassium carbonate and $18 \mathrm{~mL}(0.24$ mol) of acetone. The mixture was stirred at $25^{\circ} \mathrm{C}$ under nitrogen for $6 \mathrm{~h}$. Since GLC analysis of the reaction mixture at this time indicated that no ethanolamine remained, an aliquot was removed, and the solvent evaporated. NMR analysis of the crude mixture showed a 5.7:1 ratio of oxazolidine $2 \mathrm{a}\left(\mathrm{R}_{1}=\mathrm{R}_{2}=\mathrm{H}, \mathrm{R}_{3}=\mathrm{R}_{4}=\right.$ $M e)$ :Schiff base $2 b\left(R_{1}=R_{2}=H, R_{3}=R_{4}=M e\right)$. This was based on the area of gem-dimethyls, $\delta 1.38$ for the oxazolidine and $\delta 2.28$ for the Schiff base. The reaction mixture was cooled to $0^{\circ} \mathrm{C}$, and nitrosyl chloride was slowly bubbled in. After being stirred for $30 \mathrm{~min}$ at $5{ }^{\circ} \mathrm{C}$, the solution was filtered, and the solvent was removed on a rotary evaporator. The residue was vacuum distilled to give $15 \mathrm{~g}(72 \%)$ of $3: \mathrm{bp} 60-61^{\circ} \mathrm{C}(1.9 \mathrm{mmHg}$ ); IR (film) 2985 , $2935,2885,1414,1370,1300,1235,1162,1045,818 \mathrm{~cm}^{-1}$; NMR $\left(\mathrm{CDCl}_{3},{ }^{1} \mathrm{H}\right) \delta 1.73(\mathrm{~s}, 6 \mathrm{H}), 3.73(\mathrm{t}, 2 \mathrm{H}), 4.15(\mathrm{t}, 2 \mathrm{H}) ; \mathrm{NMR}$ $\left(\mathrm{CDCl}_{3},{ }^{13} \mathrm{C}\right) 94.14 \mathrm{ppm}(\mathrm{C}-2), 43.05(\mathrm{C}-3), 62.18(\mathrm{C}-4), 26.36\left(\mathrm{CH}_{3}\right.$ on C-2); MS, $m / z$ (relative intensity) $130\left(4.5 \mathrm{M}^{+}\right), 115(1.1), 91$ (3.8), 86 (10.1), 84 (5.5), 59 (12.3), 58 (39), 56 (3.6), 50 (9), 43 (100), 42 (11).

Anal. Calcd for $\mathrm{C}_{5} \mathrm{H}_{10} \mathrm{~N}_{2} \mathrm{O}_{2}: \mathrm{C}, 46.15 ; \mathrm{H}, 7.69 ; \mathrm{N}, 21.54$. Found: C, 46.18; H, 7.72; N, 21.70 .

N-Nitroso-2,2,5-trimethyloxazolidine (4). A solution of 20 $\mathrm{g}(0.266 \mathrm{~mol})$ of 1-amino-2-propanol in $250 \mathrm{~mL}$ of methylene chloride was condensed with acetone as described above. NMR analysis of the reaction mixture indicated a $6.1: 1$ ratio of the oxazolidine $2 \mathrm{a}\left(\mathrm{R}_{1}=\mathrm{H}, \mathrm{R}_{2}=\mathrm{R}_{3}=\mathrm{R}_{4}=\mathrm{Me}\right)$ : Schiff base $\mathbf{2 b}\left(\mathrm{R}_{1}\right.$ $=H, R_{2}=R_{3}=R_{4}=M e$ ). The reaction mixture was cooled to $0^{\circ} \mathrm{C}$, treated with nitrosyl chloride, and worked up as described above. Distillation of the crude product gave $28.4 \mathrm{~g}(75 \%)$ of 4 : bp $61^{\circ} \mathrm{C}(1.3 \mathrm{mmHg})\left(\right.$ lit. $^{3}$ bp $\left.64^{\circ} \mathrm{C}(0.2 \mathrm{mmHg})\right)$; NMR $\left(\mathrm{CDCl}_{3}\right.$, $\left.{ }^{13} \mathrm{C}\right), 18.64 \mathrm{ppm}\left(\mathrm{CH}_{3}\right.$ on $\left.\mathrm{C}-5\right), 25.98$ and $27.69\left(\mathrm{CH}_{3}\right.$ on $\left.\mathrm{C}-2\right), 49.32$ (C-4), 69.63 (C-5), 95.00 (C-2).

N-Nitroso-2,2,4-trimethyloxazolidine (5). Condensation of $2 \mathrm{~g}(0.027 \mathrm{~mol})$ of 2 -amino-1-propanol with acetone was carried out as described above; $12 \mathrm{~h}$ were required to complete the reaction. The mixture was nitrosated and worked up as described above to give $2.2 \mathrm{~g}(58 \%)$ of $5:$ bp $45-46^{\circ} \mathrm{C}(1.5 \mathrm{mmHg}) ; \mathrm{IR}$ (film) $2985,2935,2880,1450,1410,1368,1275,1228,1000,828 \mathrm{~cm}^{-1}$; $\mathrm{NMR}\left(\mathrm{CDCl}_{3},{ }^{1} \mathrm{H}\right) 1.27(\mathrm{~d}, 3 \mathrm{H}), 1.69(\mathrm{~s}, 3 \mathrm{H}), 1.76(\mathrm{~s}, 3 \mathrm{H}), 3.78$ $(\mathrm{q}, 1 \mathrm{H}), 4.12(\mathrm{q}, 1 \mathrm{H}), 4.45(\mathrm{~m}, 1 \mathrm{H})$; the $Z$ isomer represented $3 \%$ of the total as calculated from the area of Me on C-4, $\delta 1.59$ (d), and gem-dimethyls, $\delta 1.50$ and $\delta 1.55 ; \mathrm{MS}, \mathrm{m} / z$ (relative intensity) $144\left(20, \mathrm{M}^{+}\right), 115(2.3), 100(12), 98(28), 84(24), 71$ (14), $70(5), 69(11), 68(30), 67$ (13), $58(58), 42(100), 41$ (63).

(7) Wiessler, M. Angew. Chem., Int. Ed. Engl. 1974, 13, 743; Wiessler, M. Tetrahedron lett. $1975,2575$.
Anal. Calcd for $\mathrm{C}_{6} \mathrm{H}_{12} \mathrm{~N}_{2} \mathrm{O}_{2}: \mathrm{C}, 49.98 ; \mathrm{H}, 8.39 ; \mathrm{N}, 19.43$. Found: C, 49.98; H, 8.34; N, 19.35 .

N-Nitroso-2,2-dimethyl-5-phenyloxazolidine (6). A $0.5 \mathrm{M}$ solution of $6.7 \mathrm{~g}(0.048 \mathrm{~mol})$ of 2-amino-1-phenylethanol in methylene chloride was condensed with acetone over a $12-\mathrm{h}$ period as described above. The ratio of the oxazolidine $2 a\left(R_{1}=H, R_{2}\right.$ $\left.=\mathrm{Ph}, \mathrm{R}_{3}=\mathrm{R}_{4}=\mathrm{Me}\right):$ Schiff base $2 \mathrm{~b}\left(\mathrm{R}_{1}=\mathrm{H}, \mathrm{R}_{2}=\mathrm{Ph}, \mathrm{R}_{3}=\mathrm{R}_{4}\right.$ $=\mathrm{Me}$ ) was $27: 1$. Nitrosation and workup was carried out as described above. The crude product was purified through drypacked silica gel (activity III), eluted with 6:1 hexane/tetrahydrofuran, to give $7.21 \mathrm{~g}(73 \%)$ of 6 as a yellow oil: bp 148-150 ${ }^{\circ} \mathrm{C}(1.2 \mathrm{mmHg})$ (purification by distillation of large quantities of this material is not recommended); IR (film) $3060,3010,2985$, $2935,2880,1950,1882,1810,1755,1605,1595,1453,1414,1370$, $1287,1168,1030,842,760,700 \mathrm{~cm}^{-1} ; \mathrm{NMR}\left(\mathrm{CDCl}_{3},{ }^{1} \mathrm{H}\right) \delta 1.78(\mathrm{~s}$, $3 \mathrm{H}), 1.91(\mathrm{~s}, 3 \mathrm{H}), 3.35(\mathrm{q}, 1 \mathrm{H}), 4.30(\mathrm{q}, 1 \mathrm{H}), 5.21(\mathrm{q}, 1 \mathrm{H}), 7.34$ $(\mathrm{s}, 5 \mathrm{H}) ; \mathrm{MS}, \mathrm{m} / z$ (relative intensity) $206\left(\mathrm{M}^{+}, 0.1\right), 105(17.6)$, 104 (100), 103 (9.3), 78 (13.8), 77 (9.3), $71(5), 70(27), 55(20), 43$ (17).

Anal. Calcd for $\mathrm{C}_{11} \mathrm{H}_{14} \mathrm{~N}_{2} \mathrm{O}_{2}: \mathrm{C}, 64.06 ; \mathrm{H}, 6.84 ; \mathrm{N}, 13.58$. Found: $\mathrm{C}, 64.20 ; \mathrm{H}, 6.90 ; \mathrm{N}, 13.48$.

erythro- $N$-Nitroso-2,2,4-trimethyl-5-phenyloxazolidine (7). A solution of $552 \mathrm{mg}(3.5 \mathrm{mmol})$ of norephedrine in $8 \mathrm{~mL}$ of methylene chloride was stirred with 2 equiv of acetone for 6 $h$ in the presence of anydrous potassium carbonate. The NMR spectrum indicates a ratio of $32: 1$ oxazolidine $2 a\left(R_{2}=P h, R_{1}\right.$ $\left.=R_{3}=R_{4}=M e\right)$ :Schiff base $2 b\left(R_{2}=P h, R_{1}=R_{3}=R_{4}=M e\right)$. The reaction mixture was nitrosated with nitrosyl chloride and worked up as described above. The product was purified on dry-packed silica gel (activity III), eluted with 6:1 hexane/THF to give $555 \mathrm{mg}(72 \%)$ of $7: \mathrm{bp}$ (oil bath temperature) $108^{\circ} \mathrm{C}(0.1$ $\mathrm{mmHg}$ ); IR (film) 3060, 3025, 2990, 1950, 1885, 1810, 1755, 1605, $1455,1420,1380,1280,1008,860 \mathrm{~cm}^{-1} ; \mathrm{NMR}\left(\mathrm{CDCl}_{3},{ }^{1} \mathrm{H}\right) \delta 0.67$ $(\mathrm{d}, 3 \mathrm{H}), 1.84(\mathrm{~s}, 3 \mathrm{H}), 1.96(\mathrm{~s}, 3 \mathrm{H}), 4.80(\mathrm{~m}, 1 \mathrm{H}, j=5.3 \mathrm{~Hz}), 5.26$ $(\mathrm{d}, 1 \mathrm{H}, J=5.3 \mathrm{~Hz})$; NMR ( $\left.\mathrm{CDCl}_{3},{ }^{13} \mathrm{C}\right) 134.63 \mathrm{ppm}, 128.32,128.07$, $125.97,94.84,77.70,54.71,29.38,26.51,12.48 ; \mathrm{MS}, \mathrm{m} / z$ (relative intensity) 119 (10), $118(100), 117$ (47.7), 115 (5.9), 91 (14), 84 (26.4), 77 (12.3), 63 (14.5).

Anal. Calcd for $\mathrm{C}_{12} \mathrm{H}_{16} \mathrm{~N}_{2} \mathrm{O}_{2}: \mathrm{C}, 65.45 ; \mathrm{H}, 7.27 ; \mathrm{N}, 12.72$. Found: C, $65.60 ; \mathrm{H}, 7.12 ; \mathrm{N}, 12.86$.

Acknowledgment. This work was supported by Contract No. N01-CO-23909 with the National Cancer Institute, DHHS. The mass spectra were recorded by $\mathrm{Mr}$. Roman and the NMR by Drs. D. Hilton and G. Chmurny.

Registry No. $1\left(R^{1}, R^{2}=H\right), 141-43-5 ; 1\left(R_{1}=H ; R_{2}=M e\right)$, 78-96-6; $1\left(\mathrm{R}_{1}=\mathrm{Me} ; \mathrm{R}_{2}=\mathrm{H}\right), 78-91-1 ; 1\left(\mathrm{R}_{1}=\mathrm{H}, \mathrm{R}_{2}=\mathrm{Ph}\right)$, 7568-93-6; $2 \mathrm{a}\left(\mathrm{R}_{1}, \mathrm{R}_{2}=\mathrm{Hi} \mathrm{R}_{3}, \mathrm{R}_{4}=\mathrm{Me}\right), 20515-62-2 ; \mathbf{2 a}\left(\mathrm{R}_{1}=\right.$ $\left.\mathrm{H} ; \mathrm{R}_{2}, \mathrm{R}_{3}, \mathrm{R}_{4}=\mathrm{Me}\right), 52837-54-4 ; 2 \mathrm{a}\left(\mathrm{R}_{1}=\mathrm{H} ; \mathrm{R}_{2}=\mathrm{Ph} ; \mathrm{R}_{3}, \mathrm{R}_{4}=\right.$ $\mathrm{Me}), 87601-24-9 ; 2 \mathrm{a}\left(\mathrm{R}_{2}=\mathrm{Ph} ; \mathrm{R}_{1}, \mathrm{R}_{3}, \mathrm{R}_{4}=\mathrm{Me}\right), 60980-85-0 ; 2 \mathrm{~b}$ $\left(\mathrm{R}_{1}, \mathrm{R}_{2}=\mathrm{H} ; \mathrm{R}_{3}, \mathrm{R}_{4}=\mathrm{Me}\right), 44604-24-2 ; 2 \mathrm{~b}\left(\mathrm{R}_{1}=\mathrm{H} ; \mathrm{R}_{2}, \mathrm{R}_{3}, \mathrm{R}_{4}\right.$ $=\mathrm{Me}), 96228-11-4 ; 2 b\left(R_{1}=H ; R_{2}=P h ; R_{3}, R_{4}=M e\right), 96228-12-5$; 2b $\left(\mathrm{R}_{2}=\mathrm{Ph} ; \mathrm{R}_{1}, \mathrm{R}_{3}, \mathrm{R}_{4}=\mathrm{Me}\right), 96228-13-6 ; 3,96228-14-7 ;(E)-4$, 77400-46-5; 5, 96228-15-8; 6, 96228-16-9; cis-7, 96228-17-0; $\mathrm{Me}_{2} \mathrm{CO}$, 67-64-1; norephedrine, 48115-38-4.

\section{The Role of Hydration and Stereoelectronic Effects in the Hydrolysis of cAMP}

\author{
Marcel H. P. van Genderen,* Leo H. Koole, \\ Raymond J. L. van Kooyk, and Henk M. Buck
}

Department of Organic Chemistry, Eindhoven University of Technology, Eindhoven, The Netherlands

\section{Received October 30, 1984}

It is well-known that the coenzyme cyclic adenosine $3^{\prime}, 5^{\prime}$-monophosphate ${ }^{1}$ is enzymatically hydrolyzed to adenosine $5^{\prime}$-monophosphate ${ }^{1}$ with a large exothermic

(1) The abbreviations used are cAMP, cyclic adenosine $3^{\prime}, 5^{\prime}$-monophosphate; 5'-AMP, adenosine $5^{\prime}$-monophosphate. 


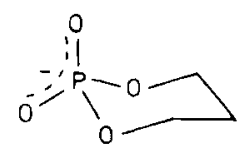

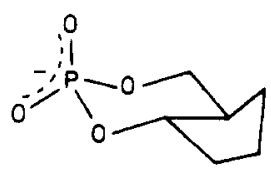

b

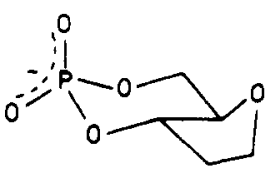

c

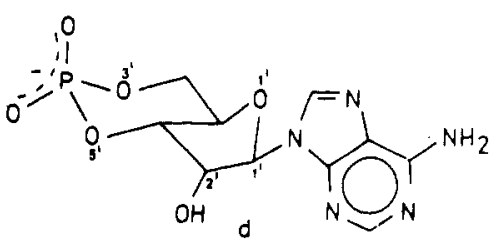

$\Delta H=-11.1 \mathrm{kcal} / \mathrm{mol}$

$د H=-3.0 \mathrm{kccl} / \mathrm{mol}$

$\Delta H=-7.6 \mathrm{kcol} / \mathrm{mol}$

$\Delta H=-10.1 \mathrm{kcal} / \mathrm{mol}$

Figure 1. Enthalpies of hydrolysis or trimethylene phosphate (a), trans-2-hydroxycyclopentanemethanol cyclic phosphate (b), trans-2-hydroxytetrahydrofuranmethanol cyclic phosphate (c), and AMP $^{1}$ (d).

enthalpy $(-11.1 \mathrm{kcal} / \mathrm{mol})$, in contrast to trimethylene phosphate $(-3.0 \mathrm{kcal} / \mathrm{mol})$. Experimental and theoretical work has demonstrated that the large exothermic enthalpy of cAMP is caused by strain, stereoelectronic effects, and solvation effects. The various contributions to the enthalpy difference between cAMP and trimethylene phosphate, i.e., $8.1 \mathrm{kcal} / \mathrm{mol}$ (vide supra), can be derived from experimental work carried out by Gerlt et al. ${ }^{2-4}$ Their calorimetric measurements showed that $4.6 \mathrm{kcal} / \mathrm{mol}$ is involved for strain, caused by the trans fusion of a cyclopentane ring to trimethylene phosphate (Figure 1). Introduction of an endocyclic oxygen results in a difference of $2.5 \mathrm{kcal} / \mathrm{mol}$, due to stereoelectronic and solvation effects. The presence of the $2^{\prime}$-hydroxyl group and the adenine base on the $1^{\prime}$ location in cAMP is responsible for the remaining $1.0 \mathrm{kcal} / \mathrm{mol}$. The aforementioned stereoelectronic effect disfavors the antiperiplanar arrangement of the phosphate oxygens $\mathrm{O}_{5^{\prime}}$ and $\mathrm{O}_{3^{\prime}}$ and the ribose oxygen $\mathrm{O}_{1^{\prime}}$ (gauche effect ${ }^{5,6}$ ). The magnitude of this gauche effect was assessed with NMR measurements of the equilibrium between axial and equatorial methoxy in 3-methoxytrimethylene phosphate. ${ }^{4}$<smiles>COC1COP(=O)([O-])OC1</smiles><smiles>COC1COP(=O)([O-])OC1</smiles>

From these measurements it followed that the axial methoxy location (oxygens gauche) is $1.0 \mathrm{kcal} / \mathrm{mol}$ lower in energy than the equatorial methoxy location (oxygens trans). Therefore Gerlt divided the enthalpy difference of $3.5 \mathrm{kcal} / \mathrm{mol}$ between the hydrolysis of trans-2hydroxycyclopentanemethanol cyclic phosphate and cAMP in $1.0 \mathrm{kcal} / \mathrm{mol}$ due to the gauche effect and $2.5 \mathrm{kcal} / \mathrm{mol}$ due to solvation effects. The experimental results are in fairly good agreement with quantum chemical calculations carried out by Scheffers-Sap and Buck. ${ }^{7}$ They found that strain relief in the ribose ring is responsible for 2.2 $\mathrm{kcal} / \mathrm{mol}$ (strain in the phosphate ring was not taken into account) of the overall $4.6 \mathrm{kcal} / \mathrm{mol}$ (vide supra). According to Scheffers-Sap and Buck the solvation effect suggested by Gerlt is a specific hydration between $\mathrm{O}_{5}$, and $\mathrm{O}_{1}$, which is absent in cAMP, since the distance between $\mathrm{O}_{5}$, and $\mathrm{O}_{1}$, is too large. They obtained for this effect a value of $2-3 \mathrm{kcal} / \mathrm{mol}$, which is in good agreement with the experimental result of $2.5 \mathrm{kcal} / \mathrm{mol}$ (vide supra). For the hydration between $\mathrm{O}_{5}$, and $\mathrm{O}_{1}$, two structures were pro-

(2) Gerlt, J. A.; Gutterson, N. I.; Datta, P.; Belleau, B.; Penney, C. L. J. Am. Chem. Soc. 1980, 102, 1655.

(3) Marsh, F. J.; Weiner, P.; Douglas, J. E.; Kollman, P. A.; Kenyon, G. L.; Gerlt, J. A. J. Am. Chem. Soc. 1980, 102, 1660.

(4) Gerlt, J. A.; Gutterson, N. I.; Drews, R. E.; Solokow, J. A. J. Am. Chem. Soc. 1980, 102, 1665.

(5) Wolfe, S. Acc. Chem. Res. 1972, 5, 102.

(6) Kirby, A. J. "The Anomeric Effect and Related Stereoelectronic Effects at Oxygen"; Springer-Verlag: Berlin, 1983; p 36. 6422 .
Table I. Measured Population Densities of the Three Rotamers around the $C_{4^{\prime}}-C_{5}$, Bond of 2 in Various Solvents

\begin{tabular}{lcccc}
\hline \multicolumn{1}{c}{ solvent } & $E_{\mathrm{T}}$ & $x\left(\mathrm{~g}^{+}\right)$ & $x\left(\mathrm{~g}^{\mathrm{t}}\right)$ & $x\left(\mathrm{~g}^{-}\right)$ \\
\hline $\mathrm{C}_{6} \mathrm{D}_{6}$ & 34.5 & 0.25 & 0.41 & 0.34 \\
$\mathrm{CDCl}_{3}$ & 39.1 & 0.33 & 0.38 & 0.29 \\
$\left(\mathrm{CD}_{3}\right)_{2} \mathrm{CO}$ & 42.2 & 0.21 & 0.45 & 0.34 \\
$\left(\mathrm{CD}_{3}\right)_{2} \mathrm{SO}$ & 45.0 & 0.17 & 0.53 & 0.30 \\
$\mathrm{CD}_{3} \mathrm{CN}$ & 46.0 & 0.26 & 0.47 & 0.27 \\
$\mathrm{CD}_{3} \mathrm{OD}$ & 55.5 & 0.27 & 0.46 & 0.26 \\
$\mathrm{D}_{2} \mathrm{O}$ & 63.1 & 0.50 & 0.41 & 0.09
\end{tabular}

posed, viz., a five-membered ring structure and a sevenmembered ring structure.

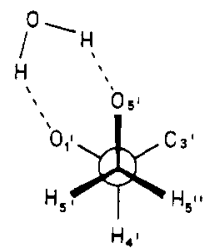

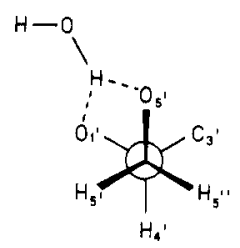

These structures were calculated to differ only 0.3 $\mathrm{kcal} / \mathrm{mol}$ in favor of the five-membered ring, ${ }^{7}$ a difference too small to select one of the structures. Presently we report new experimental work concerning the magnitude of the gauche effect and the solvation structure, based on a conformational analysis of the model systems 1 and 2 . In particular we focused on the conformation around the $\mathrm{C}_{4^{\prime}}-\mathrm{C}_{5^{\prime}}$ linkage, which determines the position of $\mathrm{O}_{5^{\prime}}$, with respect to $\mathrm{O}_{1}$. The $\mathrm{C}_{4},-\mathrm{C}_{5^{\prime}}$ conformation can be described as an equilibrium between the three staggered rotamers gauche $(+),\left(\mathrm{g}^{+}\right)$, gauche (trans), $\left(\mathrm{g}^{\mathrm{t}}\right)$, and gauche $(-),\left(\mathrm{g}^{-}\right)$.

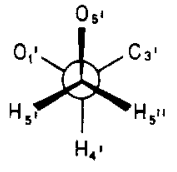

$9^{+}$

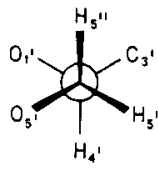

$g^{t}$

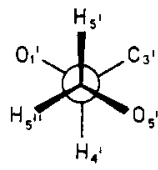

$9^{-}$
The population densities $x\left(\mathrm{~g}^{+}\right), x\left(\mathrm{~g}^{\mathrm{t}}\right)$, and $x\left(\mathrm{~g}^{-}\right)$of these rotamers were calculated from the NMR spin-spin coupling constants $J_{\mathrm{H}_{4} \mathrm{H}_{5}{ }^{\prime}}$ and $J_{\mathrm{H}_{4}{ }^{\prime} \mathrm{H}_{5}{ }^{\prime \prime}}$ as described by Koole et al. ${ }^{8}$ Using this method, we were able to obtain an independent value for the magnitude of the gauche effect of $1.0 \mathrm{kcal} / \mathrm{mol}$ (vide supra). In order to isolate the gauche effect from other factors, we used the simplified model system 1. The thermodynamic parameters of the con-

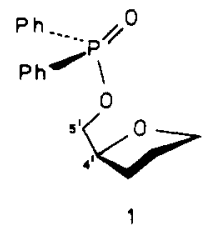

(8) (a) Koole, L. H.; Lanters, E. J.; Buck, H. M. J. Am. Chem. Soc. 1984, 106, 5451. (b) Haasnoot, C. A. G.; de Leeuw, F. A. A. M.; Altona, C. Tetrahedron 1980, 36, 2783 . 

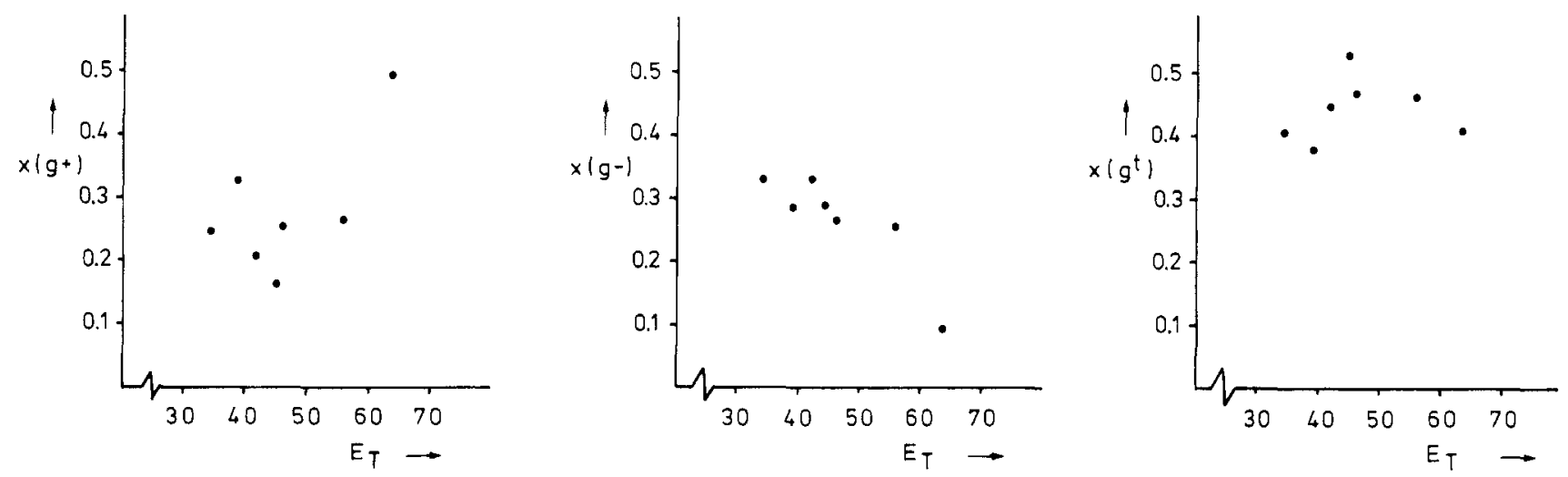

Figure 2. Population densities of the rotamers in solvents of varying polarity. ${ }^{10}$

formational equilibrium around $\mathrm{C}_{4}, \mathrm{C}_{5^{\prime}}$ were determined with variable-temperature NMR spectroscopy. Compilation of the conformational data at various temperatures in a van't Hoff plot yielded $\Delta H^{\circ}\left(\mathrm{g}^{-}, \mathrm{g}^{+}\right)=-0.9 \mathrm{kcal} / \mathrm{mol}$, $\Delta S^{\circ}\left(\mathrm{g}^{-}, \mathrm{g}^{+}\right)=-1.3 \mathrm{cal} / \mathrm{mol} \cdot \mathrm{K}, \Delta H^{\circ}\left(\mathrm{g}^{-}, \mathrm{g}^{\mathrm{t}}\right)=-1.2 \mathrm{kcal} / \mathrm{mol}$, and $\Delta S^{\circ}\left(\mathrm{g}^{-}, \mathrm{g}^{\mathrm{t}}\right)=-2.0 \mathrm{cal} / \mathrm{mol} \cdot \mathrm{K} .{ }^{9}$ Since in cAMP the $\mathrm{C}_{4^{\prime}}, \mathrm{C}_{5^{\prime}}$ bond is locked in the $\mathrm{g}^{-}$conformation, while in $5^{\prime}$-AMP the $\mathrm{g}^{+}$rotamer is dominant, our value of 0.9 $\mathrm{kcal} / \mathrm{mol}$ for the gauche effect is in excellent agreement with Gerlt's observation. The solvation structure in $5^{\prime}$. AMP was elucidated by determination of the $\mathrm{C}_{4}-\mathrm{C}_{5^{\prime}}$ conformation of 2 in various solvents. In Figure 2, the rotamer

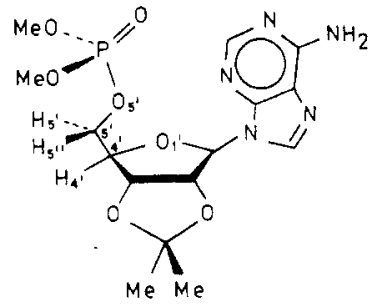

2

populations of $\mathrm{g}^{+}, \mathrm{g}^{\mathrm{t}}$, and $\mathrm{g}^{-}$are represented as functions of the solvent polarity $E_{\mathrm{T}}{ }^{10}$ It appears that the population of the $\mathrm{g}^{-}$rotamer, in which $\mathrm{O}_{5}$, is trans to $\mathrm{O}_{1}$, increases as the solvent polarity is lowered. This can be attributed to a charge repulsion between $\mathrm{O}_{5}$, and $\mathrm{O}_{1}$, which becomes more effective at lower polarities. No particular trends are observed for the variations of the $\mathrm{g}^{+}$and $\mathrm{g}^{\mathrm{t}}$ rotamer populations with $E_{\mathrm{T}}$. However, it can be seen directly that $\mathrm{g}^{+}$is the dominant $\mathrm{C}_{4^{\prime}}-\mathrm{C}_{5^{\prime}}$ rotamer in water, whereas $\mathrm{g}^{\mathrm{t}}$ is clearly preferred in all other solvents including methanol. This change in preference must be due to a specific solvation between $\mathrm{O}_{5^{\prime}}$ and $\mathrm{O}_{1^{\prime}}$ in water that favors the $\mathrm{g}^{+}$ rotamer. It seems reasonable to assume that this solvation has a seven-membered ring structure that can exist in water only.

\section{Experimental Section}

Spectroscopy. ${ }^{1} \mathrm{H}$ NMR spectra were run in the FT mode at $300 \mathrm{MHz}$ on a Bruker CXP-300 spectrometer and at $500 \mathrm{MHz}$ on a Bruker WM-500 spectrometer. Both instruments are interfaced with an ASPECT 2000 computer. A standard computer simulation-iteration procedure $\mathrm{e}^{11}$ was employed to obtain accurate

(9) $\Delta H^{\circ}\left(\mathrm{g}^{-}, \mathrm{g}^{+}\right)$and $\Delta H^{\circ}\left(\mathrm{g}^{-}, \mathrm{g}^{\mathrm{t}}\right)$ denote the enthalpy differences $H^{\circ}\left(\mathrm{g}^{-}\right)$ $-H^{\circ}\left(\mathrm{g}^{+}\right)$and $H^{\circ}\left(\mathrm{g}^{-}\right)-H^{\circ}\left(\mathrm{g}^{\mathrm{t}}\right)$, respectively, while $\Delta S^{\circ}\left(\mathrm{g}^{-}, \mathrm{g}^{+}\right)$and $\Delta S^{\circ}\left(\mathrm{g}^{-}\right.$ $\left.\mathrm{g}^{t}\right)$ denote the entropy differences $S^{\circ}\left(\mathrm{g}^{-}\right)-S^{\circ}\left(\mathrm{g}^{+}\right)$and $S^{\circ}\left(\mathrm{g}^{-}\right)-S^{\circ}\left(\mathrm{g}^{t}\right)$, respectively. The van't Hoff plots showed little scatter (straight lines with $\left.r^{2}=0.997\right),{ }^{8}$ indicating the reliability of the numerical values.

(10) The solvent polarity is not expressed as the bulk dielectric constant but as the empirically determined micropolarity $E_{\mathrm{T}}$. See: March J. “Advanced Organic Chemistry", McGraw-Hill: New York, 1977; p 335 and references cited there. values for spin-spin coupling constants. ${ }^{31} \mathrm{P}$ NMR spectra were run in the FT mode at $36.4 \mathrm{MHz}$ on a Bruker HX-90 spectrometer with a Digilab FT-NMR-3 pulsing accessory. ${ }^{31} \mathrm{P}$ chemical shifts are related to $85 \% \mathrm{H}_{3} \mathrm{PO}_{4}$ as an external standard.

Synthesis. [(Tetrahydrofurfuryl)oxy]diphenylphosphine Oxide (1). This compound was prepared as described in ref 8 .

Dimethoxy (dimethylamino) phosphine. Phosphorus trichloride $(0.5 \mathrm{~mol}, 69 \mathrm{~g})$ was added over $30 \mathrm{~min}$ to trimethyl phosphite $(1 \mathrm{~mol}, 124 \mathrm{~g})$ that was kept at $60^{\circ} \mathrm{C}$. After completion of the addition the reaction mixture was cooled to $0^{\circ} \mathrm{C}$ and diluted with $500 \mathrm{~mL}$ of sodium-dried diethyl ether. Dimethylamine (3 mol, $135 \mathrm{~g}$ ) was bubbled through the reaction mixture. After filtration of the dimethylamine hydrochloride, evaporation of the diethyl ether yielded a yellowish oil that was distilled twice at $45 \mathrm{~mm}$ through a $20-\mathrm{cm}$ Vigreux to afford $46 \mathrm{~g}(22 \%)$ of the desired product: bp $51-52{ }^{\circ} \mathrm{C} ;{ }^{1} \mathrm{H}$ NMR $\left(\mathrm{C}_{6} \mathrm{D}_{6}\right) \delta 2.63(6 \mathrm{H}, \mathrm{d}$, $\left.\mathrm{N}\left(\mathrm{CH}_{3}\right)_{2}, J_{\mathrm{PNCH}_{3}}=8.8 \mathrm{~Hz}\right), 3.42\left(6 \mathrm{H}, \mathrm{d}, \mathrm{OCH}_{3}, J_{\mathrm{POCH}_{3}}=12.0 \mathrm{~Hz}\right)$; ${ }^{31} \mathrm{P}$ NMR $\left(\mathrm{C}_{6} \mathrm{D}_{6}\right) \delta 147.6$.

2',3'-O-Isopropylideneadenosin-5'-yl Dimethyl Phosphite. A magnetically stirred solution of $2^{\prime}, 3^{\prime}-O$-isopropylideneadenosine $e^{12}$ $(6.51 \mathrm{mmol}, 2.00 \mathrm{~g})$ in $30 \mathrm{~mL}$ of dry 1,4-dioxane was kept at 85 ${ }^{\circ} \mathrm{C}$. A solution of dimethoxy(dimethylamino)phosphine (11.20 mmol, $1.53 \mathrm{~g}$ ) in $10 \mathrm{~mL}$ of dry 1,4-dioxane was added over $3 \mathrm{~h}$. After stirring for $15, \mathrm{~h}$ at $85^{\circ} \mathrm{C}$, thin-layer chromatography (TLC) with methyl ethyl ketone (MEK) as eluent showed the $2^{\prime}, 3^{\prime}-O$ isopropylideneadenosine $\left(R_{f} 0.21\right)$ to be completely converted in the product $\left(R_{f} 0.52\right)$. Evaporation of the solvent afforded a viscous, yellowish oil that was separated on a Woelm silica gel column using dry MEK as eluent. Pure $2^{\prime}, 3^{\prime}-O$-isopropylideneadenosine-5'-yl dimethyl phosphite was obtained as a white crystalline material in $79 \%$ yield: $\mathrm{mp} \cdot 164-165^{\circ} \mathrm{C}$; ${ }^{1} \mathrm{H}$ NMR $\left(\mathrm{CDCl}_{3}\right) \delta 1.41\left(3 \mathrm{H}, \mathrm{s}, \mathrm{CH}_{3}\right.$ isopropylidene), $1.64\left(3 \mathrm{H}, \mathrm{s}, \mathrm{CH}_{3}\right.$ isopropylidene), $3.47\left(6 \mathrm{H}, \mathrm{d}, \mathrm{OCH}_{3}, J_{\mathrm{POCH}_{3}}=10.8 \mathrm{~Hz}\right), 4.00(2$ $\left.\mathrm{H}, \mathrm{m}, \mathrm{H}_{5^{\prime}} / \mathrm{H}_{5^{\prime \prime}}\right), 4.48\left(1 \mathrm{H}, \mathrm{m}, \mathrm{H}_{4^{\prime}}\right), 5.05\left(1 \mathrm{H}, \mathrm{dd}, \mathrm{H}_{3^{\prime}}\right), 5.39(1 \mathrm{H}$, dd, $\left.\mathrm{H}_{2^{\prime}}\right), 6.19\left(3 \mathrm{H}, \mathrm{m}, \mathrm{H}_{1^{\prime}} / \mathrm{NH}_{2}\right), 8.04\left(1 \mathrm{H}, \mathrm{s}, \mathrm{H}_{8}\right), 8.36(1 \mathrm{H}, \mathrm{s}$, $\left.\mathrm{H}_{2}\right) ;{ }^{31} \mathrm{P}$ NMR $\left(\mathrm{CDCl}_{3}\right) \delta 141.1$. Anal. Calcd for $\mathrm{C}_{15} \mathrm{H}_{22} \mathrm{~N}_{5} \mathrm{O}_{6} \mathrm{P}$ : C, 45.11; H, 5.55; N, 17.54. Found: C, 44.95; H, 5.68; N, 18.06.

$2^{\prime}, 3^{\prime}$-O -Isopropylideneadenosin-5'-yl Dimethyl Phosphate (2). $2^{\prime}, 3^{\prime}-O$-Isopropylideneadenosin-5'-yl dimethyl phosphite (1.13 mmol, $450 \mathrm{mg}$ ) was dissolved in $25 \mathrm{~mL}$ of dry dichloromethane and an ozone-oxygen (15:85) stream was bubbled through. After $35 \mathrm{~min}$, TLC with MEK as eluent showed the reaction to be complete $\left(R_{f} 0.27\right)$. Evaporation of the dichloromethane yielded the product as a hygroscopic white solid in $96 \%$ yield: ${ }^{1} \mathrm{H}$ NMR $\left(\mathrm{CDCl}_{3}\right) \delta 11.40\left(3 \mathrm{H}, \mathrm{s}, \mathrm{CH}_{3}\right.$ isopropylidene), $1.62\left(3 \mathrm{H}, \mathrm{s}, \mathrm{CH}_{3}\right.$ isopropylidene $), 3.72\left(6 \mathrm{H}\right.$, d, $\left.\mathrm{OCH}_{3}, J_{\mathrm{POCH}_{3}}=11.0 \mathrm{~Hz}\right), 4.28(2$ $\left.\mathrm{H}, \mathrm{m}, \mathrm{H}_{5^{\prime}} / \mathrm{H}_{5^{\prime \prime}}\right), 4.51\left(1 \mathrm{H}, \mathrm{m}, \mathrm{H}_{4^{\prime}}\right), 5.13\left(1 \mathrm{H}, \mathrm{dd}, \mathrm{H}_{3^{\prime}}\right), 5.46(1 \mathrm{H}$, dd, $\left.\mathrm{H}_{2}\right), 6.19\left(1 \mathrm{H}, \mathrm{d}, \mathrm{H}_{1^{\prime}}\right), 6.42\left(2 \mathrm{H}, \mathrm{br} \mathrm{s}, \mathrm{NH}_{2}\right), 8.08\left(1 \mathrm{H}, \mathrm{s}, \mathrm{H}_{8}\right)$, $8.48\left(1 \mathrm{H}, \mathrm{s}, \mathrm{H}_{2}\right) ;{ }^{31} \mathrm{P}$ NMR $\left(\mathrm{CDCl}_{3}\right) \delta 1.4$. Anal. Calcd for $\mathrm{C}_{15} \mathrm{H}_{22} \mathrm{~N}_{5} \mathrm{O}_{7} \mathrm{P}: \mathrm{C}, 43.37 ; \mathrm{H}, 5.34 ; \mathrm{N}, 16.87$. Found: $\mathrm{C}, 43.41 ; \mathrm{H}$, $5.44 ; \mathrm{N}, 17.09$.

Acknowledgment. This investigation has been supported by the Netherlands Foundation for Chemical Re-

(11) PANIC program: Bruker Spectrospin AG, Switzerland.

(12) Fromageot, H. P. M.; Griffin, B. E.; Reese, C. B.; Sulston, J. E. Tetrahedron 1967, 23, 2315. 
search (SON) with financial aid from the Netherlands Organization for the Advancement of Pure Research (ZWO). The $500-\mathrm{MHz}^{1} \mathrm{H}$ NMR spectra were run at the Dutch National $300 / 500$ high field NMR facility at Nijmegen. We thank Dr. J. W. de Haan for valuable discussions and L. J. M. van de Ven and P. van Dael (Nijmegen) for the technical assistance in recording the NMR spectra.

Registry No. 1, 91237-85-3; 2, 96259-12-0; cAMP, 60-92-4; trimethyl phosphite, 121-45-9; dimethylamine, 124-40-3; dimethoxy(dimethylamino)phosphine, 20217-54-3; $2^{\prime}, 3^{\prime}$ - $O$-isopropylideneadenosine, $362-75-4 ; 2^{\prime}, 3^{\prime}-O$-isopropylideneadenosin5'-yl dimethyl phosphite, 96259-13-1.

\section{Two-Dimensional NMR Studies of Marine Natural Products. 2.1 Utilization of Two-Dimensional Proton Double Quantum Coherence NMR Spectroscopy in Natural Products Structure Elucidation-Determination of Long-Range Couplings in Plumericin}

Gary E. Martin,* Radhika Sanduja, and Maktoob Alam

Department of Medicinal Chemistry, College of Pharmacy, University of Houston-University Park, Houston, Texas 77004

Received October 11, 1984

Two-dimensional NMR experiments have provided a convenient means of access to multiple quantum information, ${ }^{2,3}$ this work leading to the development of the proton double quantum experiment recently described by Mareci and Freeman. ${ }^{4}$ Although the proton double quantum technique has been applied to large molecule,,-9 there have been no reported applications of the technique in natural products structure elucidation. We would therefore like to report the isolation of plumericin (1) from

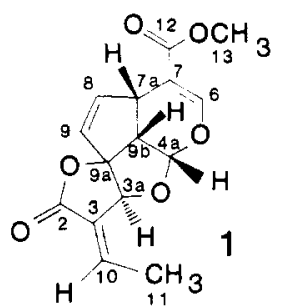

Cliona caribboea and the utilization of the proton double quantum experiment to uncover spin coupling pathways where $J \sim 0 \mathrm{~Hz}^{3,6,9}$ which were not observed in the much more commonly utilized COSY experiment. ${ }^{10-12}$ The as-

(1) For the previous paper in this series, see: Martin, G. E.; Sanduja, R.; Alam, M. J. Nat. Prod., submitted for publication.

(2) Bodenhausen, G. Prog. Nucl. Magn. Reson. Spectrosc. 1981, 14, 137. Sørensen, O. W.; Eich, G. W.; Levitt, M. H.; Bodenhausen, G.; Ernst, R. R. Ibid. 1983, 16, 163 .

(3) Braunschweiler, L.; Bodenhausen, G.; Ernst, R. R. Molec. Phys. $1983,48,535$.

(4) Mareci, T. H.; Freeman, R. J. Magn. Reson. 1983, 51, 531

(5) Boyd, J.; Dobson, C. M.; Redfield, C. J. Magn. Reson. 1983, 55, 170.

(6) Homans, S. W.; Dwek, R. A.; Fernandes, D. L.; Rademacher, T. W. Biochem. Biophys. Acta 1984, 798, 78.

(7) Hanstock, C. C.; Lown, J. W. J. Magn. Reson. 1984, 58, 167.

(8) Macura, S.; Kumar, N. G.; Brown, L. R. Biochem. Biophys. Res. Commun. 1983, 117, 486. Macura, S.; Kumar, N. G.; Brown, L. R. J. Magn. Reson. 1984, 60, 99 .

(9) Wagner, G.; Zuiderweg, E. Biochem. Biophys. Res. Commun. 1983, 113,854 .

(10) Aue, W. P.; Bartholdi, E.; Ernst, R. R. J. Chem. Phys. 1976, 64, 2229.

(11) Bax, A.; Freeman, R. J. Magn. Reson. 1981, 44, 542.

(12) Bax, A.; Freeman, R.; Morris, G. A. J. Magn. Reson. 1981, 42, 164.

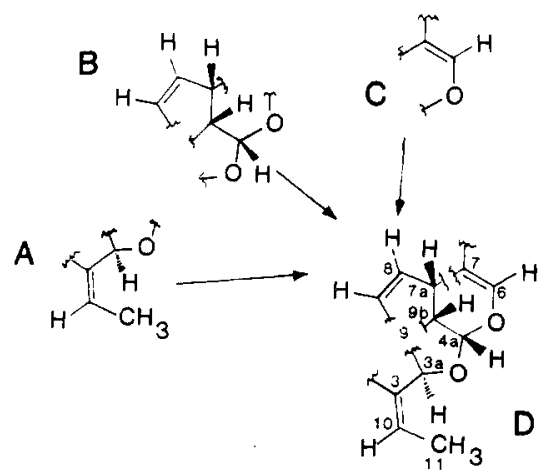

Figure 1. Structural fragments of plumericin assembled (A-C) from COSY data and from the two-dimensional proton double quantum spectrum (D) shown in Figure 2.

signment of the ${ }^{13} \mathrm{C}$ NMR spectrum of 1 is also reported through the use of two-dimensional proton-carbon heteronuclear chemical shift correlation techniques. ${ }^{13-15}$

\section{Results and Discussion}

On the basis of the $300-\mathrm{MHz}^{1} \mathrm{H}$ NMR spectrum and mass spectral data, 1 was tentatively identified as plumericin (3-ethylidine-3,3a,7a,9b-tetrahydro-2-oxo- $2 \mathrm{H}, 4 \mathrm{H}$ 1,4,5-trioxa-1H-dicyclopent [a,hi]indene-7-carboxylic acid methyl ester). The unprecedented occurrence of plumericin (1) in a marine invertebrate prompted us to initiate a carefully detailed study of the molecule. We were especially interested in the examination of the molecule for long-range spin-coupling pathways which would link together the several discrete proton spin systems contained in the structure despite the fact that no long-range coupling information was contained in the previous reports on the structure determination ${ }^{16}$ or in the COSY spectrum. Rather than utilizing variants of the COSY experiment intended to emphasize long-range couplings, ${ }^{11,17,18}$ we instead employed the proton double quantum experiment ${ }^{4}$ which should also be suitable for this purpose. ${ }^{3,6,9}$

Structural fragments of plumericin (1) which are shown in Figure 1 were assembled from a COSY spectrum (not shown). Initial attempts at linking these components via homonuclear decoupling were unsuccessful because of the digitization employed during the survey decoupling experiments, thus representing a potential source of ambiguity in either the case of molecules of unknown structure or in those cases where the molecule is somewhat larger and the possibilities of selecting a permuted connectivity consequently are greater.

The proton double quantum coherence spectrum, ${ }^{4}$ shown in Figure 2, did successfully link the structural components derived from the COSY experiment to afford the single large structural fragment shown in Figure 1. The final structure of the molecule follows directly from the large structural fragment. The utility of the proton double quantum experiment derives from several of its features which are worthy of further comment. First, responses in the double quantum frequency domain $\left(\omega_{1}\right.$ or $\left.F_{1}\right)$ are observed at the algebraic sum of the offsets of the coupled spins from the carrier frequency $(0 \mathrm{~Hz}$ on the axis above

(13) Maudsley, A. A.; Ernst, R. R. Chem. Phys. Lett. 1977, 50, 369

(14) Bodenhausen, G.; Freeman, R. J. Magn. Reson, 1977, 28, 471.

(15) Bax, A.; Morris, G. A. J. Magn. Reson. 1981, 42, 401.

(16) Kupchan, S. M.; Dessertin, A. L.; Baylock, B. T.; Bryan, R. F. J. Org. Chem. 1977, 39, 2477 and references cited therein.

(17) Bax, A. "Two-Dimensional Nuclear Magnetic Resonance in Lipids"; Delft University Press-D. Reidel Publishing Co.: Boston, 1982, pp 85-86.

(18) Steffens, J. C.; Rorak, J. L.; Lynn, D. G.; Riopel, J. L. J. Am. Chem. Soc. 1983, 105, 1669. 